\title{
Ready-to-Cook Fish Steaks from Catla Fish with High Nutritional Value and Longer Shelf Life
}

\section{Priyam Sharma* Bibha Chetia Borah}

Fisheries Research Center, Assam Agricultural University, Jorhat, Assam, India

*Corresponding Author: Priyam Sharma, Fisheries Research Center,

Assam Agricultural University, Jorhat, Assam, India.

DOI: $10.31080 /$ ASNH.2020.04.0733
Received: June 18, 2020

Published: July 20, 2020

(C) All rights are reserved by Priyam Sharma and Bibha Chetia Borah.

\begin{abstract}
The demand for fish is very high in the NE Region of India, where 95-100\% of populations of the constituent states are fish eaters. As domestic production is not sufficient to meet the demand of people, the gap between demand and production is met by importing from other states and neighboring countries. However the preservation and transportation process exercised for the import, always leaves a question mark regarding quality of the product. Processing of raw fish to make it pan-ready is often not convenient for consumers particularly for the urban population. The present communication deals with development of a protocol for 'ready-tocook' steak from Catla (Catla catla) with good nutritional quality and longer shelf life to meet consumers' demand. The present communication includes quality evaluation of Catla fish steaks treated with different antimicrobial agents viz., dry salt (T1), vinegar (T2), salt + turmeric (T3), salt+ turmeric + vinegar (T4), vacuum packed and stored for a period of 21 days at $-18^{\circ} \mathrm{C}$ at definite interval of days and assessment of its economic viability for commercial application. Out of the treatments, T4 was the best treatment in view of the highest average crude protein content (20.11\%), ash content (0.189\%), acceptability (8.94), taste value (8.94), flavor (8.44) and texture value (8.81) with zero microbial load up to 21 days of storage. The results indicate a viable protocol for entrepreneurship development through commercial production of 'ready-to-cook' fish steaks from Catla with high nutritional quality and long shelf life up to 21 days of storage.
\end{abstract}

Keywords: Fish Steaks; Antimicrobial; Shelf Life; Ready-To-Cook; Catla; Nutritional Quality; Vacuum Packing

\section{Introduction}

Fish is regarded as one of the most human health friendly, nutritious food items throughout the globe. Besides being a rich source of easily digestible protein, fish is also a reliable source of vitamins, minerals, unsaturated fatty acids and essential micronutrients. However, as a highly perishable commodity, fish requires appropriate post-harvest processing and preservation measure to retain its nutrient status and other desirable qualities [1]. Different techniques like processing, addition of special ingredients, packaging methods are employed for fish preservation and value addition, which in one way or other modifies or improves the nature of the raw product resulting in different end products that vary in sensory characteristics, nutrient content, convenience for consum- ers and shelf life [2]. In the global food market, 'ready-to-cook' or 'ready-to-serve' products have been replacing the traditional raw food products to meet the consumers' preference particularly in urban areas for coping up with the fast paced lifestyle [3]. Several ready to cook and ready to serve fish products (fish ball, fish finger, fish fillet, fish cutlet etc.) have been developed in India to satisfy the taste buds of this section of people with different nutrient level, taste, texture and appearance as well as shelf life [2,3].

High demand for fish prevails in the NE Region of India, as 90 - $100 \%$ of the populations of the eight constituent states of the region are fish eaters and fish has been an integral component of their daily diet. Good quality fish is however not available throughout the year in the region, as the growing demand for fish surpasses the 
domestic production. The gap between demand and production is being met through import from other Indian states like Andhra Pradesh, Uttar Pradesh and West Bengal and even from neighboring country Bangladesh. The method of packing and preservation for long distance transportation of fish from these places to NE Region however always leaves a question mark about its human health friendliness. Processing of fresh fish every day to make it 'pan-ready' is also time-consuming and often not convenient for consumers particularly for the urban areas where the people are leading a very fast paced life. As such, developing human health friendly fish products with desirable level of nutrition, longer shelf life and also as per with the consumers' convenience and preference, is the call of the hour to address these issues.

However, very few products are available in this part of the country to meet the consumers' demand. Although 'ready-to-cook' frozen marine fish products are somewhat available in the market; fresh water fish products preferred by the local population is not available. In fact, the value addition to freshwater fish has not gained the desired momentum due to lack of specific technologies. Among different processed products, fish steaks (large dressed fish cut into cross section slices with bones) are preferred commonly for preparation of local traditional dishes. In view of the above, the present study was proposed for development of ready to cook fish steaks with desired nutrient quality, sensory characteristics and shelf life from commonly preferred fresh water fish species of the region by using the human health friendly bio preservation technique.

\section{Materials and Methods \\ Fish species used}

The fish species taken for the experiment was Catla (Catla cat$l a$ ), one of the three members of the highly preferred and commercially important cultivable fish group 'Indian Major Carps'. For the study Catla fish (weighing $1.5-2.0 \mathrm{~kg} /$ fish each) were collected from the culture ponds of Fisheries Research Center, Assam Agricultural University, Jorhat, using a dragnet with minimum stress to the fish (Figure 1). The fishes were processed immediately after catching (before the Rigor mortis stage) to retain the quality of the fish flesh intact.

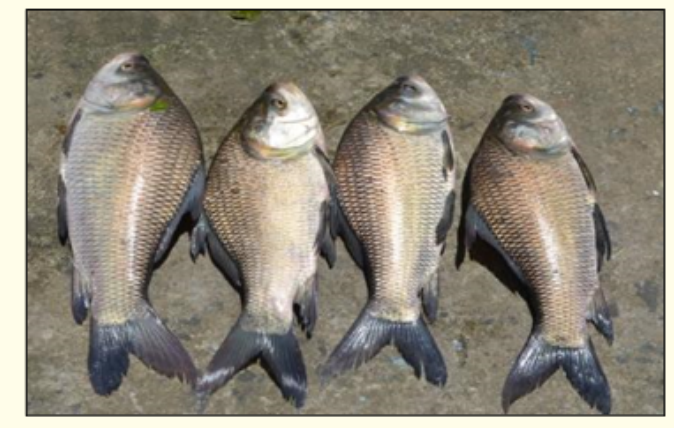

Figure 1: Experimental fish Catla catla.

\section{Location and period of study}

The study was conducted at Fisheries Research Centre, Assam Agricultural University, Jorhat, Assam, India, situated on the south bank of the river Brahmaputra, at $26^{\circ} 46 / \mathrm{N}$ Latitude and $94^{0} 13 / \mathrm{E}$ longitude and $87.0 \mathrm{~m}$ above the mean sea level.

\section{Preparation of fish steaks}

Fishes were washed with potable water to remove any undesired substance (dirt, slime etc.) and then processed (degutted, de scaled and de headed) and cut into steaks of uniform sizes by using a sharp knife (each steak weighing 100 gram \pm 10 gram) (Figure 2). The steaks were then washed with potable water to remove blood and slime at room temperature and treated with different agents.

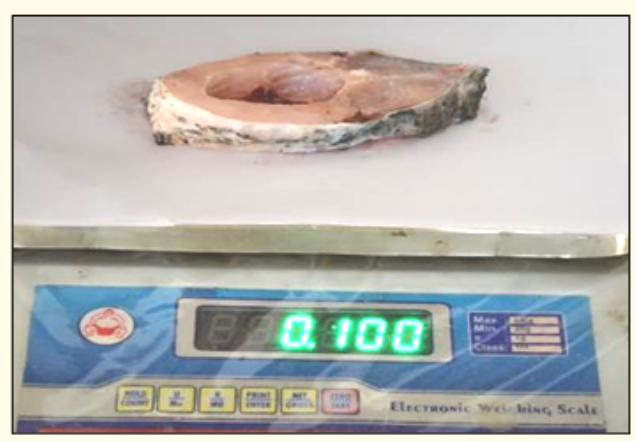

Figure 2: Preparation of fish steak. 


\section{Treatments}

The treatments were done with three commonly used preservatives with antimicrobial properties, viz. common salt $(\mathrm{NaCl})$, turmeric (Curcuma longa) and white vinegar $\left(\mathrm{CH}_{3} \mathrm{COOH}\right)$, in different combinations and doses as shown below. The fixation of doses for the preservatives was based on standard methods [4-6]. All the fish steaks (treated and control) were packed using HDPE material, followed by vacuum packing and sealing. Vacuum packed and sealed packets were then stored in deep freezer at $-18^{\circ} \mathrm{C}$ for 21 days (Figure 3). Analysis of different parameters was done at 7 days interval.

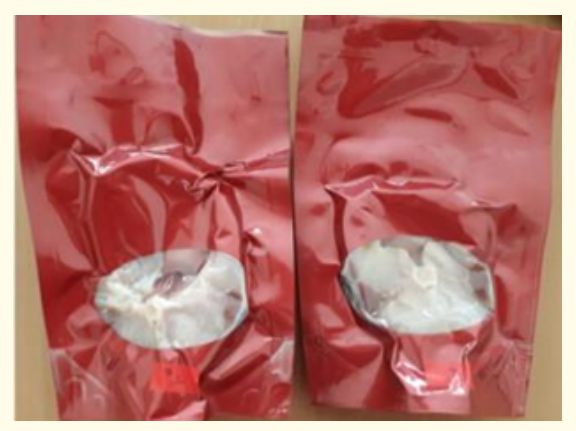

Figure 3: Treated fish steaks after vacuum packing.

\section{Treatments}

- $\mathrm{T}_{1}$ : Dry salt, $30 \mathrm{~g} / 100 \mathrm{~g}$ of fish steak+vacuum packing

- $\mathrm{T}_{2}$ : Vinegar, $8 \mathrm{ml} / 100 \mathrm{~g}$ of fish steak+vacuum packing

- $\quad \mathrm{T}_{3}$ : Dry salt $15 \mathrm{~g}+$ turmeric $2.5 \mathrm{~g} / 100 \mathrm{~g}$ of fish steak+vacuum packing

- $\quad \mathrm{T}_{4}$ : (Dry salt $10 \mathrm{~g}+$ turmeric $1.6 \mathrm{~g}+$ vinegar $2.6 \mathrm{ml} / 100 \mathrm{~g}$ of fish steak) +vacuum packing

- $\quad$ Control: Without any preservative + vacuum packing.

Methodology for analysis

Processing of fish steaks for the study

For the analysis, the frozen fish steaks were thawed for 3 hours at room temperature. After thawing the steaks were deboned and homogenized in a homogenizer for analysis of different parameters viz. moisture content, ash content, crude fat content, crude protein content and microbial load. For the analysis of texture profile and sensory evaluation, the whole fish steak was taken.

\section{Analysis of moisture content}

The moisture content of the samples was determined as per the procedure of AOAC [7], by using the following formula,

Moisture (g/100 g of sample $)=\frac{\left(\mathrm{W}_{1}-\mathrm{W}_{2}\right)}{\mathrm{W}} \times 100$

Where,

$\mathrm{W}=$ Weight of the sample $(\mathrm{g})$

$\mathrm{W}_{1}=$ Initial weight $(\mathrm{g})$

$\mathrm{W}_{2}=$ Final weight $(\mathrm{g})$.

\section{Determination of ash content}

The total ash (mineral content) content was determined as per the procedure of AOAC [8] and calculated by using the following formula:

$$
\text { Total mineral }(\% \mathrm{w} / \mathrm{w})=\frac{\left(\mathrm{W}_{3}-\mathrm{W}_{1}\right)}{\left(\mathrm{W}_{2}-\mathrm{W}_{1}\right)} \times 100
$$

Where,

$\mathrm{W}_{1}=$ Weight of the crucible $(\mathrm{g})$

$\mathrm{W}_{2}=$ Weight of the crucible + sample $(\mathrm{g})$

$\mathrm{W}_{3}=$ Weight of the crucible + ash $(\mathrm{g})$.

\section{Analysis of crude protein content}

Crude protein content of the samples was determined with modified A.O.A.C. [7] method. Predigested, digested and distilled samples, taken in conical flasks were titrated with $0.1 \mathrm{~N} \mathrm{HCl}$ till the color changes from bluish green to pale pink and the burette readings were recorded accordingly. The calculation of the Crude pro- 
tein content was done with the following formula:

(Sample titre-blank titre) x Normality of $\mathrm{HCl}$ $\mathrm{x}$ volume made up of the digest

$\% \mathrm{~N}=$ $\mathrm{x} 100$

'Aliquot of the digest taken' $x$ 'mg sample'

Analysis of crude fat

Crude fat was determined with modified A.O.A.C. [7] procedure and was calculated by the following formula:

$$
\left(\mathrm{W}_{2}-\mathrm{W}_{1}\right)
$$

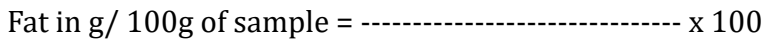

$$
\text { Weight of the sample (g) }
$$

\section{Assessment of microbial load}

The microbial load was determined by following standard procedure for sterilization and preparation of PDA media, preparation of samples, followed by plating of samples by using a laminar flow system. The plates were then put in BOD incubator at $180^{\circ} \mathrm{C}$ for 24 hours. After 24 hours total microbial load was counted (cfu/g).

\section{Texture profile analysis (TPA)}

The texture of the samples was measured using a texture analyzer (TA.HD Plus, Stable Microsystems Ltd., Godalming; Surrey, United Kingdom). All measurements were carried out at $25^{\circ} \mathrm{C}$, with load shell $100 \mathrm{~kg}$ and puncture probe $\mathrm{p} / 5$. Texture parameters were calculated by the "Exponent software" installed on the instrument in 3 replications.

\section{Sensory evaluation}

Fish steaks were taken out from the deep freezer and thawed at room temperature for three hours after taking out from the packets. These were then fried in rice bran oil at $105^{\circ}$ temperature for 5 minutes each in a non-stick cooking pan. The fried fish steaks samples were then subjected to sensory analysis i.e. color, taste, texture, flavor, appearance and overall acceptability by 13 semitrained panelists, as per standard procedure. The judges rated the quality characteristics of randomly coded sample on a nine-point hedonic rating scale. Product characterization was carried out under daylight illumination and in isolated booths within a sensory laboratory.

\section{Statistical analysis}

The mean data for each parameter were subjected to analysis of variance for two factorial completely randomized designs as described by Panse and Sukhatame [9]. The treatment mean squares were tested for significance by F-test and the difference of treatment means were tested by estimating critical difference.

The standard error of differences (S.Ed. \pm ) was calculated by using the following expression:

S.Ed $\pm=\sqrt{\frac{2 \times \text { Error mean square }}{\text { Pooled number of replication }}}$

\section{Analysis of economic viability}

Economic viability was studied by calculating the total cost of large scale production (500 kg) of ready-to-cook fish steaks from Catla fishes on the basis of market price of different inputs, then fixing the sale price on the basis of a market survey on similar products and by calculating the profit percentage and benefit-cost (B.C) ratio.

\section{Results and Discussion}

The bio preservation is the process by which the microbial action and proliferation can be inhibited in preserved food and is achieved by adding different agents that have specific antimicrobial property. The results of the present experiment depicted varying levels of success in bio preservation of the fish steaks treated with different agents and stored up to 21 days under refrigeration. The change in the moisture content (\%) up to the $21^{\text {st }}$ day of storage showed a significant decreasing trend across the day's interval (Table 1). The average highest moisture content was found in day $1(79.95 \%)$ and average lowest moisture content was found on day $21(73.84 \%)$. While along the treatment, the average highest moisture content was found in Control (78.30\%) and the average lowest moisture content was found in $\mathrm{T}_{4}(75.62 \%)$. The reduction of 


\begin{tabular}{|c|c|c|c|c|c|}
\hline & D1 & D7 & D14 & D21 & Mean \\
\hline Control & $80.47 \pm 0.12$ & $79.13 \pm 0.12$ & $77.20 \pm 0.20$ & $76.40 \pm 0.20$ & 78.30 \\
\hline $\mathrm{T}_{1}$ & $80.27 \pm 0.12$ & $78.47 \pm 0.12$ & $75.60 \pm 0.20$ & $74.33 \pm 0.50$ & 77.17 \\
\hline $\mathrm{T}_{2}$ & $79.80 \pm 0.20$ & $78.60 \pm 0.20$ & $76.47 \pm 0.31$ & $74.53 \pm 0.46$ & 77.35 \\
\hline $\mathrm{T}_{3}$ & $79.60 \pm 0.20$ & $78.47 \pm 0.31$ & $75.73 \pm 0.12$ & $72.33 \pm 0.31$ & 76.53 \\
\hline $\mathrm{T}_{4}$ & $79.60 \pm 0.20$ & $77.60 \pm 0.35$ & $73.67 \pm 0.12$ & $71.60 \pm 0.20$ & 75.62 \\
\hline \multirow[t]{2}{*}{ Mean } & 79.95 & 78.45 & 75.73 & 73.84 & \\
\hline & \multicolumn{2}{|c|}{ S.Ed.( $( \pm)$} & \multicolumn{3}{|c|}{ C.D.(5\%) } \\
\hline $\mathrm{T}$ & \multicolumn{2}{|c|}{0.10} & \multicolumn{3}{|c|}{0.20} \\
\hline D & \multicolumn{2}{|c|}{0.09} & \multicolumn{3}{|c|}{0.18} \\
\hline $\mathrm{T} \times \mathrm{D}$ & \multicolumn{2}{|c|}{0.21} & \multicolumn{3}{|c|}{0.40} \\
\hline
\end{tabular}

Table 1: Changes in moisture content (\%) of fish steaks stored up to 21 days.

moisture content is because of the action of different antimicrobial agents, used in the treatments, which through the process of osmosis, draw out water from the cells of fish muscle. Salt, when used as preservative, replaces a portion of the water naturally present in the fish muscle through the process of osmosis [10]. Decrease in moisture content is an indication of success of the preservation technique as lack of moisture inhibits microbial growth.

The result of ash content (\%) analysis revealed a significant decreasing trend along with the different day's interval, across the 21 days (Table 2). The average highest ash content was found in Day $1(0.231 \%)$ and average lowest ash content was found in Day $21(0.184 \%)$. While along the treatment, the average highest ash content was found in Control $(0.218 \%)$ and the average lowest ash content was found in $\mathrm{T}_{3}(0.196 \%)$. The highest ash content on $21^{\text {st }}$ days of storage was retained by $\mathrm{T}_{4}(0.189 \pm 0.01)$. In the present study the decrease in ash content along with day's interval is attributable to the drip loss (loss of meat juice), caused due to the process of freezing and thawing for analysis, which results in loss of some water soluble vitamins and other nutrients [11,12].

The fat content in a fish may vary widely according to the species, age, season, food availability and health status of the fish and even in different body parts of the same fish [13]. In the present study (Table 3), average highest total crude fat content was recorded in day $1(2.50 \%)$ and the average lowest crude fat content was recorded in day $21(2.26 \%)$. While along the treatments the average highest crude fat content was found in Control $(2.63 \%)$ and

\begin{tabular}{|l|c|c|c|c|c|}
\hline & D1 & D7 & D14 & D21 & Mean \\
\hline Control & $0.253 \pm 0.01$ & $0.227 \pm 0.01$ & $0.207 \pm 0.01$ & $0.187 \pm 0.01$ & 0.218 \\
\hline $\mathrm{T}_{1}$ & $0.233 \pm 0.01$ & $0.193 \pm 0.01$ & $0.193 \pm 0.01$ & $0.183 \pm 0.01$ & 0.201 \\
\hline $\mathrm{T}_{2}$ & $0.247 \pm 0.01$ & $0.207 \pm 0.03$ & $0.187 \pm 0.01$ & $0.183 \pm 0.02$ & 0.206 \\
\hline $\mathrm{T}_{3}$ & $0.207 \pm 0.01$ & $0.203 \pm 0.01$ & $0.197 \pm 0.01$ & $0.177 \pm 0.01$ & 0.196 \\
\hline $\mathrm{T}_{4}$ & $0.213 \pm 0.01$ & $0.200 \pm 0.02$ & $0.197 \pm 0.01$ & $0.189 \pm 0.01$ & 0.200 \\
\hline Mean & 0.231 & 0.206 & 0.196 & 0.184 & \\
\hline & \multicolumn{2}{|c|}{ S.Ed.( \pm ) } & \multicolumn{3}{|c|}{ C.D.(5\%) } \\
\hline $\mathrm{T}$ & \multicolumn{2}{|c|}{0.005} & \multicolumn{3}{|c|}{0.010} \\
\hline $\mathrm{D}$ & \multicolumn{2}{|c|}{0.005} & \multicolumn{3}{|c|}{0.020} \\
\hline $\mathrm{T}$ x D & \multicolumn{2}{|c|}{0.010} & \multicolumn{3}{|}{} \\
\hline
\end{tabular}

Table 2: Changes in ash content (\%) in fish steaks stored up to 21 days.

average lowest crude fat content was found in $\mathrm{T}_{4}(2.11 \%)$. Crude fat content showed a significant decreasing trend of the treatments along with the day's interval, this loss of crude fat occurred mainly attributable to the losses in triglyceride fraction due to the action of anti-microbial agents and oxidation rancidity during storage [14].

\begin{tabular}{|c|c|c|c|c|c|}
\hline & D1 & D7 & D14 & D21 & Mean \\
\hline Control & $2.73 \pm 0.15$ & $2.65 \pm 0.50$ & $2.65 \pm 0.06$ & $2.48 \pm 0.26$ & 2.63 \\
\hline $\mathrm{T}_{1}$ & $2.50 \pm 0.36$ & $2.20 \pm 0.14$ & $2.18 \pm 0.24$ & $2.18 \pm 0.13$ & 2.26 \\
\hline $\mathrm{T}_{2}$ & $2.88 \pm 0.31$ & $2.65 \pm 0.31$ & $2.53 \pm 0.39$ & $2.40 \pm 0.22$ & 2.61 \\
\hline $\mathrm{T}_{3}$ & $2.23 \pm 0.19$ & $2.20 \pm 0.14$ & $2.18 \pm 0.22$ & $2.15 \pm 0.06$ & 2.19 \\
\hline $\mathrm{T}_{4}$ & $2.15 \pm 0.19$ & $2.13 \pm 0.19$ & $2.10 \pm 0.35$ & $2.08 \pm 0.10$ & 2.11 \\
\hline \multirow[t]{2}{*}{ Mean } & 2.50 & 2.37 & 2.33 & 2.26 & \\
\hline & \multicolumn{2}{|c|}{ S.Ed. ( \pm ) } & \multicolumn{3}{|c|}{ C.D. $(5 \%)$} \\
\hline $\mathrm{T}$ & \multicolumn{2}{|c|}{0.09} & \multicolumn{3}{|c|}{0.17} \\
\hline $\mathrm{D}$ & \multicolumn{2}{|c|}{0.08} & \multicolumn{3}{|c|}{0.16} \\
\hline$T \times D$ & \multicolumn{2}{|c|}{ NS } & \multicolumn{3}{|c|}{ NS } \\
\hline
\end{tabular}

Table 3: Changes in the fat content (\%) in fish steaks stored up to 21 days.

The analysis of protein content revealed (Table 4) that the average highest total crude protein content was in day 1 (19.65\%) and the average lowest crude protein was in day 21 (18.69\%). While along the treatments the average highest crude protein content was found in $\mathrm{T}_{4}(20.11 \%)$ and average lowest crude protein content was found in Control (17.90\%). The decrease in protein con- 
tent in different treatments in the present study during storage may be due to protein denaturation and loss in gelatin caused by extended frozen storage and also due to proteolysis induced by enzymatic activities of psychotropic microbial growth in the control [14]. In salted fish, where the salt concentration reached about 20 per cent, high ionic strength caused contraction of the myofibrils and dehydration of proteins.

\begin{tabular}{|l|c|c|c|c|c|}
\hline & D1 & D7 & D14 & D21 & Mean \\
\hline Control & $18.25 \pm 1.25$ & $18.08 \pm 0.50$ & $17.77 \pm 0.99$ & $17.52 \pm 0.70$ & 17.90 \\
\hline $\mathrm{T}_{1}$ & $20.15 \pm 0.65$ & $19.65 \pm 0.23$ & $19.15 \pm 1.21$ & $18.65 \pm 0.98$ & 19.40 \\
\hline $\mathrm{T}_{2}$ & $19.20 \pm 0.86$ & $19.20 \pm 0.22$ & $19.16 \pm 0.67$ & $18.91 \pm 0.69$ & 19.12 \\
\hline $\mathrm{T}_{3}$ & $20.08 \pm 1.06$ & $19.58 \pm 1.12$ & $19.33 \pm 0.28$ & $18.58 \pm 1.12$ & 19.39 \\
\hline $\mathrm{T}_{4}$ & $20.58 \pm 0.99$ & $20.08 \pm 0.52$ & $20.00 \pm 0.41$ & $19.78 \pm 0.60$ & 20.11 \\
\hline Mean & 19.65 & 19.32 & 19.08 & 18.69 & \\
\hline & \multicolumn{2}{|c|}{ S.Ed.( \pm ) } & \multicolumn{3}{|c|}{ C.D.(5\%) } \\
\hline $\mathrm{T}$ & \multicolumn{2}{|c|}{0.29} & \multicolumn{3}{|c|}{0.56} \\
\hline $\mathrm{D}$ & \multicolumn{2}{|c|}{0.26} & \multicolumn{3}{|c|}{$\mathrm{NS}$} \\
\hline $\mathrm{T} \times \mathrm{D}$ & \multicolumn{2}{|c|}{$\mathrm{NS}$} & \multicolumn{4}{|c}{} \\
\hline
\end{tabular}

Table 4: Changes in the crude protein content (\%) in fish steaks stored up to 21 days.

The results of analysis of microbial load (Table 5), revealed that the average highest total microbial load was recorded in day 1 (10.13 cfu/g) and the average lowest microbial load was recorded in day 14 and day 21 ( $0.20 \mathrm{cfu} / \mathrm{g}$ ). While along the treatments the average highest microbial load was found in Control $(7.08 \mathrm{cfu} / \mathrm{g}$ ) and average lowest microbial load content was found in $\mathrm{T}_{2}$ and $\mathrm{T}_{4}(1.50 \mathrm{cfu} / \mathrm{g})$. In all the treatments, the microbial load was zero from $7^{\text {th }}$ day onwards, while in the control, the antimicrobial load showed a decreasing trend (24.67 cfu/g to $1.33 \mathrm{cfu} / \mathrm{g}$ ) indicating the efficiency of the antimicrobials used for treatments in checking the microbial growth as well as of the chilling temperature and vacuum packing in controlling the microbial growth. These findings were in agreement with Binsi., et al. [15], who stated that vacuum packaging significantly improved the sensory and microbiological quality of fish and increases the shelf life. Salting of fish removes water and lowers the water activity (water available for the support of microbial growth which causes the spoilage) and thus bacterial growth is retarded [16]. Turmeric has an anti-bac- terial protection against fungus and other pathogenic microbes. Vinegar having low $\mathrm{pH}$ inhibits the growth of microbes such as Escherichia coli, Enterococcus, or Bacteroides fragilis bacteria etc. (Johnston., et al. 2006).

\begin{tabular}{|c|c|c|c|c|c|}
\hline & D1 & D7 & D14 & D21 & Mean \\
\hline Control & $24.67 \pm 4.16$ & $1.33 \pm 0.58$ & $1.00 \pm 0.00$ & $1.33 \pm 0.58$ & 7.08 \\
\hline$T_{1}$ & $7.67 \pm 2.52$ & 0 & 0 & 0 & 1.92 \\
\hline $\mathrm{T}_{2}$ & $6.00 \pm 4.00$ & 0 & 0 & 0 & 1.50 \\
\hline $\mathrm{T}_{3}$ & $6.33 \pm 3.79$ & 0 & 0 & 0 & 1.58 \\
\hline $\mathrm{T}_{4}$ & $6.00 \pm 1.00$ & 0 & 0 & 0 & 1.50 \\
\hline \multirow[t]{2}{*}{ Mean } & 10.13 & 0.27 & 0.20 & 0.27 & \\
\hline & \multicolumn{2}{|c|}{ S.Ed. $( \pm)$} & \multicolumn{3}{|c|}{ C.D.(5\%) } \\
\hline $\mathrm{T}$ & \multicolumn{2}{|c|}{0.68} & \multicolumn{3}{|c|}{1.33} \\
\hline $\mathrm{D}$ & \multicolumn{2}{|c|}{0.61} & \multicolumn{3}{|c|}{1.19} \\
\hline$T \times D$ & \multicolumn{2}{|c|}{1.36} & \multicolumn{3}{|c|}{2.67} \\
\hline
\end{tabular}

Table 5: Changes in the microbial load (cfu/g) in fish steaks stored up to 21 days.

The value of the texture characteristics of the samples showed a decreasing trend with the increase in storage period (Table 6). This was in accordance with the findings of Pearce., et al. (2011), who found that the storage temperature generally has a distinctive effect on fish texture measurement. The decreasing value of texture profile in the present study indicated that there was change in physical characteristics of the fish steak with the advancement of storage days due to change in moisture content and other parameters. The average highest texture profile was recorded in day 1 (849.23 g/sec) and average lowest texture profile in day 21 (482.55 $\mathrm{g} / \mathrm{sec}$ ). Along the treatments, the average highest texture profile was found in Control (835.21 g/sec) and the average lowest texture profile was found in $\mathrm{T}_{2}(572.18 \mathrm{~g} / \mathrm{sec})$.

From the results of different analysis it was found that the $\mathrm{T}_{4}$ was the most effective treatment from the view point of retaining maximum protein content and ash content up to 21 days of storage in the treated fish. As fish is an important source of protein, the product with retention of highest protein content at the end of shelf life will be regarded as best value added product among all the treatments. The results of sensory evaluation (Figure 4) 


\begin{tabular}{|c|c|c|c|c|c|}
\hline & D1 & D7 & D14 & D21 & Mean \\
\hline Control & 937.27 & 936.62 & 879.39 & 587.58 & 835.21 \\
\hline $\mathrm{T}_{1}$ & 715.18 & 621.00 & 661.82 & 608.48 & 651.62 \\
\hline $\mathrm{T}_{2}$ & 754.53 & 653.09 & 621.42 & 259.66 & 572.18 \\
\hline $\mathrm{T}_{3}$ & 948.81 & 872.62 & 642.19 & 379.41 & 710.76 \\
\hline $\mathrm{T}_{4}$ & 890.36 & 617.95 & 617.97 & 577.60 & 675.97 \\
\hline Mean & 849.23 & 740.26 & 684.56 & 482.55 & \\
\hline & \multicolumn{2}{|c|}{ S.Ed.( \pm$)$} & \multicolumn{3}{|c|}{ C.D.(5\%) } \\
\hline $\mathrm{T}$ & \multicolumn{2}{|c|}{9.37} & \multicolumn{3}{|c|}{18.37} \\
\hline $\mathrm{D}$ & \multicolumn{2}{|c|}{8.38} & \multicolumn{3}{|c|}{16.43} \\
\hline $\mathrm{T} \times \mathrm{D}$ & \multicolumn{2}{|c|}{16.23} & \multicolumn{3}{|c|}{31.81} \\
\hline
\end{tabular}

Table 6: Changes in texture profile $(\mathrm{g} / \mathrm{sec})$ in fish steaks stored up to 21 days.

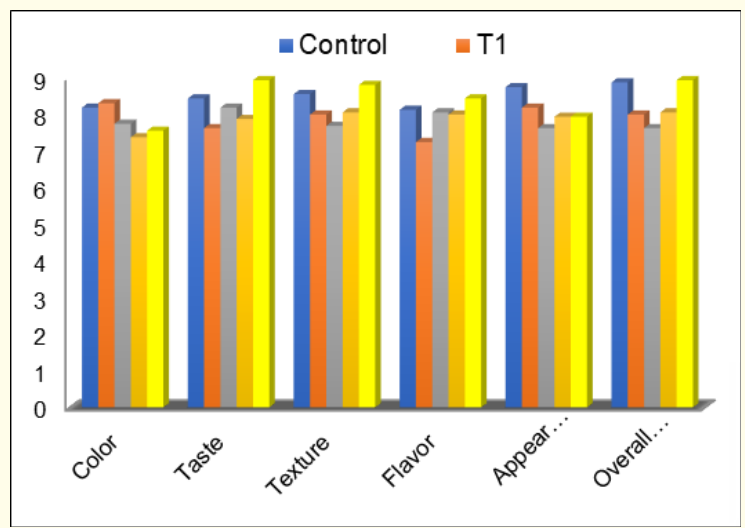

Figure 4: Average variations in sensory parameters under different treatments up to 21 days.

also support this statement, as according to sensory evaluation, $\mathrm{T}_{4}$ was the best treatment (dry salt $10 \mathrm{~g}+$ turmeric $1.6 \mathrm{~g}+$ vinegar 2.6 $\mathrm{ml} / 100 \mathrm{~g}$ of steak.) with highest taste value (8.94), highest texture value (8.81), highest flavor value (8.44) and overall acceptability (8.94).

\section{Conclusion}

From the present study it can be concluded that the fish steaks treated with dry salt, turmeric and vinegar in prescribed doses (dry salt $10 \mathrm{~g}+$ turmeric $1.6 \mathrm{~g}+$ vinegar $2.6 \mathrm{ml} / 100 \mathrm{~g}$ of steak.) was the best of all the products and the ready-to-cook fish steaks produced through this treatment can be marketed up to 21 days of storage with high level of nutrition and sensory value and without any microbial load. The findings of the study will fill the gap of scientific information in this field and pave the way for entrepreneurship development on ready-to-cook nutritious fish product. This will help farmers in doubling their income from the same produce though human health friendly value addition, as per the motto of the 'Blue Revolution' recently launched by the Prime Minister of India. The findings will also open a new avenue for human health friendly preservation of fish for long distance transport for longer period of time.

\section{Acknowledgement}

The authors express their sincere gratitude to Dr. Chandan Hazarika, Former Director of Post Graduate Studies, Assam Agricultural University, Jorhat, Assam, Dr. Ananta Saikia, Professor, Dept. of Horticulture, AAU, Dr. Pranati Das, Professor and Head, Dept. of Food Science and Nutrition, College of Community Science, AAU, Dr. Pranab Dutta, Scientist, Dept. of Plant Pathology, AAU and Dr. Runima Sarmah, Professor, Dept. of Biochemistry and Agril. Chemistry,AAU, Dr. Manashi Das Purukayastha, Assistant Professor and Mr. Soumitra Goswami, Assistant Professor, Dept. of Horticulture (Food Science and Technology) and Mrs. Barsha Neog, Assistant Professor, Dept. of Agricultural Statistics, Assam Agricultural University for their continuous guidance and support.

\section{Bibliography}

1. Clucas IJ and Sctcliffe PJ. "An introduction to fish handling and processing". Report of the Tropical Products Institute (1987): 143-186.

2. Pagarkar AU., et al. "Value addition is need of seafood industries". Fishcoops 23.4 (2011): 8-17.

3. Kolekar AD and Pagarkar AU. "Quality evaluation of readyto-eat fish ball in curry". SAARC Journal of Agriculture 11.1 (2013): 35-43.

4. Farid FB., et al. "Effect of Sun-drying on proximate composition and pH of Shoal fish (C. striatus; Bloch, 1801) treated with Salt and Salt-turmeric storage at Room Temperature (270 $\left.300^{\circ} \mathrm{C}\right)$ ". IOSR Journal of Agriculture and Veterinary Science 7.9 (2014): 01-08. 
5. U.S.FDA Report on Fish and Fishery Products Hazards and Controls Guidance. 4th edition. Center for food safety and applied nutrition (1995).

6. Akter S., et al. "Studies on the performance of turmeric with salt as a preservative for the curing of two lean fishes in laboratory condition". Bangladesh Journal of Zoology 35 (2007): 49-60.

7. AOAC. Official Methods of Analysis Association of Official Analytical Chemists, Washington, D.C., USA (2000).

8. AOAC. Official method of analysis. Association of Official Agricultural Chemists, Washington, D.C., USA (1970).

9. Panse VG and Sukhatame PV. "Statistical method for agricultural workers". Indian Counsil of Agricultural Research, New Delhi (1978).

10. Fennema OR. Food Chemistry. 3rd ed. New York: Marcel Dekker (1996).

11. Froning GW., et al. "Moisture levels in frozen poultry as related to thawing losses, cooking losses, and palatability". Poultry Science 37 (1960): 328.

12. Bender AE. Food Processing and Nutrition. New York: Academic Press (1978).

13. Murray J and Burt JR. The Composition of Fish. FAO in partnership with Support unit for International Fisheries and Aquatic Research, SIFAR (2001).

14. Mazrouh MM. "Effects of freezing storage on the biochemical composition in muscles of Saurida undosquamis comparing with imported frozen fish". International Journal of Fisheries and Aquatic Studies 3.2 (2015): 295-299.

15. Binsi KP., et al. "Microbiological and shelf life characteristics of eviscerated and vacuum packed freshwater catfish (Ompok pabda) during chill storage". Journal of Food Science and Technology 52 (2013): 1424-1433.

16. Gallart JL., et al. "A comparative study of brine salting of Atlantic cod (Gadus morhua) and Atlantic salmon (Salmo salar)". Journal of Food Engineering 79.1 (2007): 261-270.

\section{Assets from publication with us}

- Prompt Acknowledgement after receiving the article

- Thorough Double blinded peer review

- Rapid Publication

- Issue of Publication Certificate

- High visibility of your Published work

Website: www.actascientific.com/

Submit Article: www.actascientific.com/submission.php

Email us: editor@actascientific.com

Contact us: +919182824667 